\title{
Hedonic Valuation of Real Estate Properties in Nigeria
}

\author{
Rotimi Boluwatife Abidoye ${ }^{1}$, and Albert P. C. Chan ${ }^{2}$
}

1,2 Department of Building and Real Estate, The Hong Kong Polytechnic University, Hung Hom, Hong Kong

To cite this article: Abidoye, R. B., \& Chan, A. P. C. (2018). Hedonic Valuation of Real Estate Properties in Nigeria. Journal of African Real Estate Research, 3(1), pp.122-140. DOI: 10.15641/jarer.v1il.452.

\begin{abstract}
Despite the wide adoption of the Hedonic Pricing Model (HPM) approach in property valuation in the real estate domain, a large number of studies conducted by real estate scholars, have tended to focus on the 'explanatory' rather than the 'predictive' ability of the technique. Given this industry focus, and thus the lack of information on the predictive nature of HPM, the present study sets out to investigate the predictive accuracy of HPM in property valuation. Data on sales transaction of residential properties were collected from registered property firms practising in the Lagos metropolis property market, in Nigeria. The collected data were divided into two categories - the training set which was fitted to the HPM developed, and the testing dataset which was used for the model validation. Accuracy metrics were used to evaluate the predictive accuracy of the HPM developed. The analysis shows that the HPM approach produced inaccurate predicted property values in terms of a high mean absolute percentage error (MAPE), mean absolute error (MAE) and root means square error (RMSE) which may not be acceptable by rational real estate investors. Also, about $60 \%$ of the predicted property values produced an inaccuracy that is $\pm 20 \%$ of the actual values, while only $26 \%$ yielded an error of margin which is within the industry acceptable margin of between \pm 0 and $10 \%$. The HPM could not be entirely relied on to produce accurate property valuation estimates. Therefore, further studies are needed to be carried out to identify more reliable and robust property valuation approaches that can produce values that would be acceptable to all property valuation stakeholders.
\end{abstract}

Keywords: Hedonic Pricing Model; Property Attributes; Valuation Inaccuracy; Property Valuation; Lagos 


\section{Introduction}

The ability to determine the accurate value of a real estate property plays a fundamental role in an economy. This is because property values influence investors' decisions (Goodhart \& Hofmann, 2008). The techniques used in estimating the values of real estate properties have been categorised into two classes, namely traditional and advanced approaches (Pagourtzi et al., 2003). None of these techniques can be viewed as the 'best' for all real-life valuation problems, this is due to the peculiar strengths and weaknesses of each approach (Lam et al., 2008). Of the advanced valuation approaches, the Hedonic Pricing Model (HPM) approach, which was introduced in the real estate domain in the early 1970s (see Rosen, 1974), has received significant acceptance by real estate researchers for property pricing estimation in different property markets around the world (Tse \& Love, 2000).

The wide popularity of the HPM technique in the real estate domain has translated into it being adopted both in practice and in theory (Schwartz, 1995). The HPM technique is commonly adopted for measuring the explanatory power of different property attributes (independent variables) on the formation of property prices (dependent variable) (Sirmans et al., 2005). This contribution could either be positive or negative contributions (Selim, 2011), due to the fact that the economic, legal, social, political and cultural landscape of property markets around the world differ (Jenkins, 2000).

Property valuation inaccuracy remains an international issue surrounding property valuation practice (Babawale, 2013a), without the exception of the Nigerian property market (Adegoke et al., 2013). The effect of property valuation inaccuracy on the economy of any nation cannot be overemphasised because both individual and corporate investors have a large proportion of their investments in real estate assets (Yalpir, 2014). Moreover, real estate valuers are usually consulted to estimate the value of properties, and a misleading property valuation estimate could adversely affect the books of a real estate investor (Taffese, 2007).

Considering the aforementioned, this study will: (1) develop an HPM equation from a dataset (training), (2) predict the holdout sample with the developed HPM equation (testing), and (3) establish the predictive accuracy of the HPM technique for accurate property valuation by evaluating the predicted values using accuracy metrics. This study will provide valuable insight into the suitability of the HPM technique to produce accurate property valuation estimates.

\section{Literature Review}

\section{The Hedonic Pricing Model}

The principles of HPM are based on the estimation of the value of composite goods, by establishing the contributory powers of each independent variable in the formation of the value of a utility bearing commodity (Limsombunchai et al., 2004). Court (1939), Muth (1966), and Lancaster (1966), amongst others, were the early studies that adopted HPM in a research endeavour. 
With reference to the real estate research domain, Haas (1922) and Wallace (1926) conducted some of the early studies that employed HPM in appraising agricultural property, while Ridker and Henning (1967) adopted it for residential property appraisal. Despite all of these research efforts, the application of HPM lacked the much-needed theoretical justification in these early days (Chin \& Chau, 2002). However, Rosen (1974), who has been widely referred to as the originator of the HPM technique, provided an explanation of HPM by developing an index for the determination of the price of automobiles. The HPM technique has been employed in solving different real-life issues which include healthcare (Berndt et al., 2000; Cutler \& Berndt, 2007), computers (Nelson et al., 1994), automobiles (Ohta \& Griliches, 1976; Triplett, 2004) and home appliances (Silver \& Heravi, 2001), to mention a few.

The theory of HPM is based on regression analysis, which could be in the form of simple regression or multiple regression (Selim, 2009). In the case of simple regression, the analysis is geared towards evaluating the relationship between a dependent variable and one independent variable. Whereas, when the relationship being investigated is between a dependent variable and more than one independent variable, then it is referred to as multiple regression (MR). MR is largely employed for real estate property price analysis because the value of a real estate property is dependent on more than one attribute (Jenkins, 2000). One of the essences of the regression analysis is to develop the best-fit representation for the relationship that exists between the dependent variable and the independent variables of the sample data being analysed (Elhag, 2002). According to Kmenta (1997), simple and multiple regression can be expressed mathematically as shown in Equations 1 and 2, respectively.

$$
\begin{aligned}
& \hat{Y}_{i}=\beta_{0}+\beta_{1} X_{1 i}+\varepsilon_{i} \\
& \hat{Y}_{i}=\beta_{0}+\beta_{1} X_{1 i}+\beta_{2} X_{2 i}+\ldots \ldots \ldots \ldots+\beta_{k} X_{k i}+\varepsilon_{i}
\end{aligned}
$$

Where $\hat{\mathrm{Y}}_{i}=$ predicted value $\beta_{0}=$ regression constant

$\beta_{1}=$ slope of $\hat{Y}$ with variable $X_{1}$ when variables $X_{2}, X_{3}, \ldots . ., X_{k}$ are held constant

$\beta_{2}=$ slope of $\hat{Y}$ with variable $X_{2}$ when variables $X_{1}, X_{3}, \ldots . ., X_{k}$ are held constant

$\beta_{k}=$ slope of $\hat{Y}_{i}$ with variable $\mathrm{X}_{\mathrm{k}}$ when variables $\mathrm{X}_{2}, \mathrm{X}_{3}, \ldots \ldots, \mathrm{X}_{\mathrm{k}-1}$ are held constant

$\varepsilon_{i}=$ random error in $\hat{\mathrm{Y}}$ for observation $\mathrm{i}$

$\beta_{1}, \beta_{2}, \beta_{3}, \ldots \ldots \ldots, \beta_{k}$ are referred to as the regression coefficients.

\section{Property Value Determinants: Previous International Studies}

The attributes that influence the price of properties have been categorised into three groups, namely: structural, locational and neighbourhood factors (Powe et al., 1995). Structural attributes describe the details of the building, locational attributes describe the property's access to social and economic facilities, while neighbourhood attributes depict the quality of the neighbourhood where the property is located (Mok et al., 1995). Chin and 
Chau (2002) posited that most structural factors contribute positively to the value of properties. This could be attributed to the fact that home-buyers mostly consider structural features when making residential decisions (Moghimi \& Jusan, 2015). The impact of these various attributes on the sale prices of properties has been investigated in different real estate markets around the world. Table 1 provides a few studies that have examined the influence of some of these property attributes on property values.

Table 1. Hedonic Pricing Model and Attributes' Studies

\begin{tabular}{ll}
\hline Attributes & Studies \\
\hline Property size & Pozo (2009), Selim (2011) \\
Floor level & Choy et al. (2007), Jim and Chen (2006), \\
Better view & Benson et al. (1998), Choy et al. (2007) \\
Balcony & Morancho (2003), Chau et al. (2004) \\
House number & Bourassa and Peng (1999), Chau et al. (2001) \\
Age of property (-ve) & Tse (2002), Choy et al. (2007), \\
Closeness to school & Downes and Zabel (2002), Clapp et al. (2008) \\
Location & Ge and Du (2007), Pozo (2009) \\
Property type & Fletcher et al. (2000) \\
Proximity to transport facilities & Mbachu and Lenono (2005), Choy et al. (2007) \\
Proximity to shopping centres & Sirpal (1994), Des Rosiers et al. (1996) \\
Proximity to place of work & Ottensmann et al. (2008) \\
Security & Ceccato and Wilhelmsson (2011), Owusu-Ansah (2012) \\
Proximity to CBD & Topcu and Kubat (2009), Sanjari (2012) \\
Number of bedrooms & Canavarro et al. (2010), Selim (2011) \\
Number of bathrooms and toilets & Ottensmann et al. (2008), Pozo (2009) \\
Parking space & Wen et al. (2005), Canavarro et al. (2010) \\
Sea view & Hui et al. (2007), Topcu and Kubat (2009), \\
Open space/parks & Nicholls and Crompton (2005), Voicu and Been (2008) \\
Place of worship & Carroll et al. (1996), Babawale and Adewunmi (2011) \\
Noise & Tomkins et al. (1998), Espey and Lopez (2000) \\
Green areas & Morancho (2003), Jim and Chen (2006) \\
Air quality & Hui et al. (2007), Ayan and Erkin (2014), \\
Landfills/waste site & Seok Lim and Missios (2007), (Ready, 2010) \\
Power lines & Sims et al. (2009), Elliott and Han (2013) \\
\hline Note: CBD means central busing & \\
\hline
\end{tabular}

Note: CBD means central business district

\section{Property Value Determinants: Previous Nigerian Studies}

In measuring the impact of various property attributes on property values in Nigeria, scholars have adopted HPM to examine the effect of the proximity of landfills (Akinjare et al., 2012), universities (Babalola et al., 2013), places of worship (Babawale, 2013b), the presence of Jacuzzi bathtubs (Otegbulu \& Johnson, 2011) and neighbourhood security (Adegoke, 2014) on property values. Other attributes are the electricity supply (Famuyiwa \& Babawale, 2014), the number of bedrooms (Oduwole \& Eze, 2013), the number of bathrooms and toilets (Babawale et al., 2012), pipe-borne water (Babawale et al., 2012), and the property size (Oduwole \& Eze, 2013), among others.

Previous studies that have adopted HPM in real estate in Nigeria have only established the explanatory relationship between property attributes and 
property values. To date, efforts have not been directed at substantiating the suitability of the technique to produce accurate and reliable property valuation estimates that can be a good proxy of property value. Therefore, there is a need to bridge the gap between 'explaining' and 'predicting' modelling, as this would provide the "reality check to the relevance" (Shmueli, 2010: p.292) of HPM for property valuation. Taken together, this study aims to establish the predictive ability of HPM for property valuation to produce accurate and reliable property valuation estimates.

\section{Property Valuation Accuracy}

Property valuation accuracy has received widespread attention from real estate researchers in different property markets around the world - the US, UK, Australia, and so on. Waldy (1997) defines valuation accuracy as the measure of the closeness or divergence of valuation estimates to the market value of a subject property. Waldy (1997) further argued that valuation variation/variance is the difference in the values arrived at by different valuers when a subject property is being appraised and should not be mistaken for valuation accuracy. The position of Crosby (2000) substantiates the argument of Waldy (1997) but adds that valuation bias occurs when there is a consistent overvaluation or undervaluation of a subject property, in relation to the sales price (target).

The issue of valuation inaccuracy could lead to the bankruptcy of real estate investors, and stakeholders rely largely on the opinion of value communicated by real estate professionals to make real estate investment decisions (Taffese, 2007). If this happens, it could lead to the questioning of the relevance, as well as the credibility of valuers. At the same time, it could reduce the confidence stakeholders have in the profession (Adegoke et al., 2013), and this will, in turn, affect the performance of the property market and inadvertently the economy of the nation at large, due to the relevance of real estate to the economic development of a nation (Chiang et al., 2015).

In a more stable property market, those variations in property valuation estimates may occur to a lesser degree, while in an unstable market, the reverse may be true (Shapiro et al., 2012). Valuation inaccuracy may be unavoidable in property valuation because different valuers interpret the property market and property value determinants differently, but there is an acceptable range of variations in estimates (Shapiro et al., 2012).

Hager and Lord (1985) posited that the range of acceptance for property valuation inaccuracy should be about $5 \%$ more or less of the average value of the subject property. Similarly, Mackmin (1985) suggested that valuation estimates produced by valuers would be acceptable if they were within $\pm 5 \%$ range of the property value. Furthermore, Hutchinson et al. (1996) argued that a valuation estimate within 5 to $10 \%$ range is acceptable, only when it is above $10 \%$ that the estimate can be subjected to contention. This argument is supported by Brown et al. (1998) who mentioned that a valuation figure $10 \%$ above or below the actual amount could lead to a valuer being accused of negligence in property value estimation. However, Crosby et al. (1998) 
mentioned that judges usually adopt the bracket of 10 to $15 \%$ to decide if a valuation figure is inaccurate. The authors argued that the accuracy of valuation figures should be based on the process adopted by valuers in arriving at such figures and not solely on the margin of error of the estimated valuation figure.

\section{Research Method}

\section{The Data}

The authors chose Nigeria as the study area because it is an emerging economy (Akinbogun et al., 2014), where the awareness and know-how of automated valuation models is limited (Abidoye \& Chan, 2016). Transactions (i.e. sales and purchases) data were collected from registered real estate firms located in the Lagos metropolis property market in Nigeria. A registered real estate firm is a firm that is registered with the Nigerian Institution of Estate Surveyors and Valuers (NIESV) and Estate Surveyors and Valuers Registration Board of Nigeria (ESVARBON). These organisations are the professional bodies that regulate the real estate professionals and profession in Nigeria. It is assumed that the data collected from NIESV and ESVARBON should be reliable due to the expected professional conduct of these legitimate organisations. Due to the unavailability of a centralised sales transaction data bank in Nigeria (Ashaolu \& Olaniran, 2016), the data collection process was limited to those firms that provided access to the information on completed transactions relating to residential properties. Therefore, structural attributes of residential properties were the major independent variables selected for this study (see Table 2). This is not uncommon in similar studies such as Do and Grudnitski (1992) and Thanasi (2016), amongst others, where structural attributes datasets were used to model property prices. The only neighbourhood variable added is the sea view, being that the study area is surrounded by water bodies (see Figure 1), and it was possible for the real estate professionals to provide such information regarding the properties included in this study. In the same vein, the location of a property was included in order to distinguish the location of each observation (property), i.e. to describe the geographical positions of the properties in the study area. The list of the 11 independent variables and one dependent variable are presented in Table 2 alongside their mean, standard deviation, minimum and maximum values.

Table 2. Descriptive Statistics of the Variables

\begin{tabular}{lcccc}
\hline Variable & Mean & Standard Deviation & Minimum & Maximum \\
\hline Dependent & & & & \\
Price in Naira ( & $149,769,541.60$ & $199,367,090.90$ & $14,500,000.00$ & $1,182,844,000.00$ \\
Independent & & & & \\
Bedrooms & 3.49 & 1.26 & 1 & 10 \\
Toilets & 4.28 & 1.37 & 1 & 7 \\
Bathrooms & 3.38 & 1.25 & 1 & 7 \\
Property type & 3.87 & 1.45 & 1 & 6
\end{tabular}




\begin{tabular}{llllc} 
Boys' quarters & 1.08 & 1.36 & 0 & 8 \\
Parking & 3.27 & 2.45 & 0 & 20 \\
Age & 3.30 & 4.97 & 0 & 42 \\
Floors & 2.83 & 2.19 & 1 & 16 \\
Security fence & 0.98 & 0.14 & 0 & 1 \\
Sea view & 0.05 & 0.22 & 0 & 1 \\
Location & 3.36 & 1.70 & 1 & 5 \\
\hline
\end{tabular}

In total, 321 complete observations were retrieved upon completion of the data collection phase of the study. These represent the details of residential properties sold and purchased in the high-income neighbourhoods of the Lagos metropolis (Island property submarket) which include Ikoyi, Victoria Island, Lekki Peninsula Phase 1 and other active neighbourhoods on the Lekki - Epe Expressway corridor (see Figure 1). The properties included in this study are located in a submarket that is amongst the finest and most vibrant property markets in Nigeria, which is occupied by high-income earners and expatriates (Babawale \& Johnson, 2012).

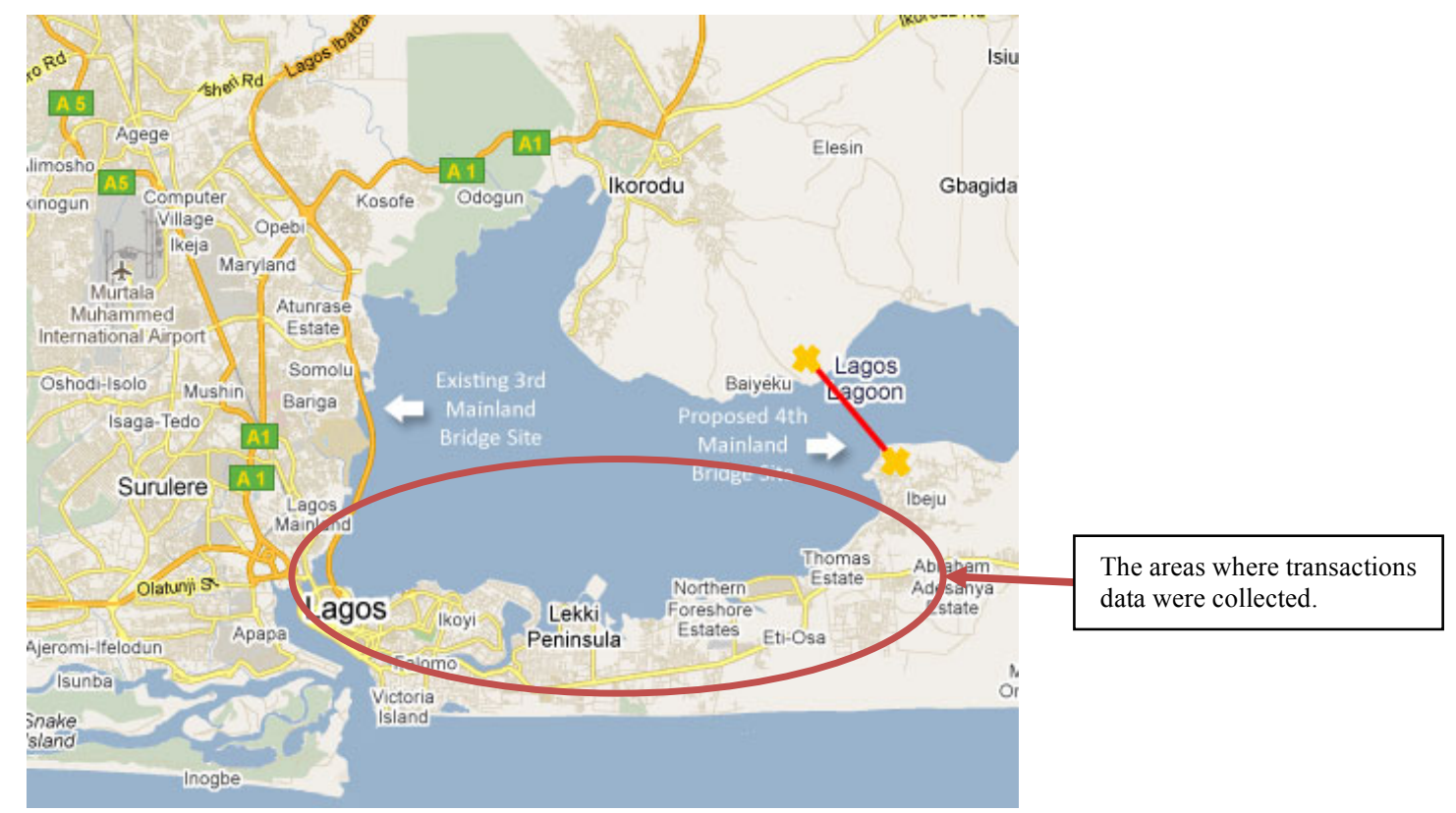

Figure 1: Map of Lagos showing the study areas under investigation

Source: http://www.lgtnigeria.com/topic page.php?id=87\&page $=1$

Table 3 provides the definition and measurement of both the dependent variable and the independent variables. Out of the 11 independent variables, the presence of security fence and sea view are dummy variables, and they are represented by the value " 1 " if they are present and " 0 " when otherwise. After the data collection exercise, it was observed that the transactions were completed between 2010 and 2016. The composite consumer price index (CPI) published by the National Bureau of Statistics (2016), was used to deflate the real estate property values. This was done to adjust for time value for money (i.e. inflation). 
Table 3. Definition, Measurement and Frequencies of the Variables

\begin{tabular}{lll}
\hline Variable & Definition & Measurement \\
\hline Price & Sale price of the property & Naira $(\AA)$, Nigerian currency \\
Bedrooms & Number of bedrooms & Numeric $(0,1,2,3 \ldots)$ \\
Toilets & Number of toilets & Numeric $(0,1,2,3 \ldots)$ \\
Bathrooms & Number of bathrooms & Numeric $(0,1,2,3 \ldots)$ \\
Property type* & Construction style of the property & Numeric $(1,2 \ldots 6)$ \\
Boys' quarters & Number of BQ rooms & Numeric $(0,1,2,3 \ldots)$ \\
Parking & Number of parking lot & Numeric $(0,1,2,3 \ldots)$ \\
Age & Property age & Numeric $(0,1,2,3 \ldots)$ \\
Floors & Number of floors & Numeric $(0,1,2,3 \ldots)$ \\
Security fence & Availability of security fence & 1 if available, and 0 otherwise \\
Sea view & Presence of sea view & 1 if available, and 0 otherwise \\
Location & Location of the property & The neighbourhood situated \\
\hline
\end{tabular}

Note: Property type includes: duplex (1), detached house (2), semi-detached house (3), terrace (4), flat (5) and others (6).

$B Q$ means boy's quarters which is called servants' quarters in some environment.

\section{Model Specification}

The selection of the variables to be included in the model started with the testing for multicollinearity between the independent variables by estimating their partial correlation coefficients. The multicollinearity test reveals a correlation between the number of bathrooms and the number of toilets in a property. The correlation coefficient of the number of bathrooms and the number of toilets was 0.965 . Consequently, the number of toilets variable was removed from the independent variables list. However, it should be noted that the presence of multicollinearity is irrelevant when adopting HPM for prediction (Nguyen \& Cripps, 2001), thus it will not affect the predictive performance of the property valuation model. The Glejser test was performed to check for heteroscedasticity. This analysis shows that there is no presence of heteroscedasticity amongst the variables because the significant coefficients of all independent variables are greater than 0.05 (Gujarati \& Porter, 2009).

The linear relationship between property prices and the independent variables was established. The scatter plot approach was adopted to visualise the association between the variables. The scatter plots show that there is a linear relationship between property prices and the independent variables. The relationship recorder here is common in real estate related studies (McGreal et al., 1998; Limsombunchai et al., 2004). There is no consensus in the literature as to the best functional form to be chosen in HPM analysis (Kryvobokov \& Wilhelmsson, 2007). However, in this study, the linear functional form was adopted. This is because it can be easily computed and also relatively easy to interpret (Lin \& Mohan, 2011). The linear functional form has also been frequently adopted in previous studies, and this could be attributed to the ease of the interpretation of the parameters (Morancho, 
2003), which is noteworthy for a study of this nature. The HPM was developed using the Statistical Package for the Social Sciences (SPSS) software, version 20.0 .

In order to test the predictive accuracy of the HPM technique, the data set was divided into two parts, i.e. for training and testing of the model. $80 \%$ (256) of the samples were used to develop the HPM equation, while the remaining $20 \%$ (65) holdout samples were used for the testing of the model. The accuracy of the model was tested based on its $r^{2}$, mean absolute percentage error (MAPE), mean absolute error (MAE), root means square error (RMSE) and ultimately, the percentage of the predicted values that are close to the actual property values (holdout samples). According to Lin and Mohan (2011), MAPE, MAE and RMSE can be estimated using the expressions in Equations 3, 4 and 5, respectively.

$$
\begin{aligned}
& \text { MAPE }=\frac{\sum_{i=1}^{\mathrm{n}}\left(\frac{\mathrm{P}_{\mathrm{i}}-\hat{\mathrm{P}}_{\mathrm{i}}}{\hat{\mathrm{P}}_{\mathrm{i}}}\right)}{\mathrm{n}} \times 100 \\
& \text { MAE }=\frac{1}{\mathrm{n}} \sum_{\mathrm{i}=1}\left(\mathrm{P}_{\mathrm{i}}-\hat{\mathrm{P}}_{\mathrm{i}}\right) \\
& \text { RMSE }=\sqrt{\frac{1}{n} \sum_{i=1}^{n}\left(\mathrm{P}_{\mathrm{i}}-\hat{\mathrm{P}}_{\mathrm{i}}\right)^{2}}
\end{aligned}
$$

Where $n$ is the number of observations, is the actual property price and is the predicted property price from the model.

\section{Results and Discussion}

\section{Empirical Results}

The result of the HPM analysis is presented in Table 4. The model produced an adjusted $r^{2}$ value of 0.76 and an $r^{2}$ value of 0.77 , which indicates that the variables included in the model explain $77 \%$ variations in the prices of properties. Most of the variables produced expected (positive) signs to property values, while others produced unexpected signs. For instance, expectedly, the age of a property had a negative sign which is consistent with the existing literature (see, for instance, Hui et al., 2007). Suggesting that an old property will usually command a lower value when compared with new ones. Unexpectedly, the effect of the number of bathrooms and the presence of a security fence in a property was negative, and it could be attributed to the localised nature of the property market, suggesting that an additional number of bathrooms may not increase the value of a property in the study area. This is similar to the findings of Nguyen and Cripps (2001) who found that an additional number of bathrooms could negatively influence property prices. In the same vein, Owusu-Ansah (2012) and Adegoke (2014), among others, found that when adequate security measures are in place in a neighbourhood, for instance: proximity to a police station, improved lighting and so on (which 
could result in a low crime rate), this would significantly increase the price of a property. However, this study found that the presence of a security fence (a security measure) in a property could negatively influence its price. This may be attributed to the fact that most of the residential neighbourhoods sampled usually have a general neighbourhood-organised security personnel in addition to each house's security guards. Suggesting that the presence of a security fence in these neighbourhoods may not be regarded as a security measure for real estate investors.

Table 4. Result of the Regression Analysis

\begin{tabular}{llll}
\hline Independent variables & Coefficient & $t$-ratio & $p$-value \\
\hline Bedrooms & 8664822.596 & 0.738 & 0.461 \\
Bathrooms & -20051336.870 & -1.448 & 0.149 \\
Property type & 8076944.769 & 1.144 & 0.254 \\
Boys' quarters & 102816020.589 & 15.151 & 0.000 \\
Parking & 9526774.351 & 2.615 & 0.009 \\
Age & -1635743.326 & -1.068 & 0.286 \\
Floors & 4539570.089 & 1.455 & 0.147 \\
Security fence & -10789691.840 & -0.229 & 0.819 \\
Sea view & 154767562.522 & 4.832 & 0.000 \\
Location & -26885403.503 & -6.176 & 0.000 \\
Constant & 98778305.063 & 1.396 & 0.164 \\
\hline$r^{2}=0.766, A d j r^{2}=0.757, F-r a t i o=80.381, n=256$ &
\end{tabular}

Of all the ten variables, the presence of a sea view and the number of boys' quarters $^{1}(\mathrm{BQ})$ in a property are the most highly significant variables that influence the price of a property. Both variables had the highest coefficients that contribute to the price formation of a property in the study area. In a similar study by Mok et al. (1995), it was found that a property that has a sea view will command a higher value. Also, the positive influence of the BQ room on the price of properties was reported in the study of Basu and Thibodeau (1998).

\section{Model Performance}

As earlier stated, in order to achieve the objectives of this study, the performance of model developed was tested using the MAPE, MAE and RMSE accuracy metrics. These approaches are commonly adopted in the literature (McCluskey et al., 2013), and the closer the value of both MAE and RMSE are to 0, the better the model (Lin \& Mohan, 2011). MAPE is a measure of the prediction error expressed in percentage. The results shown in Table 5 reveals an MAE value of N61,408,856 and an RMSE value of N103,370.573. In addition, a MAPE value of $38.23 \%$ was recorded which depicts that the predictions produced an average error of $38 \%$, which may not be acceptable by a rational real estate stakeholder. These suggest that there is

\footnotetext{
${ }^{1}$ Boys Quarters (BQ) refers to servants' or maid's quarters on a property
} 
some level of inaccuracies in the HPM approach prediction, this is despite the satisfactory $r^{2}$ value of 0.77 . This confirms that the performance of a model could not be evaluated entirely by adopting the $r^{2}$ value (Willmott, 1981). The findings of the study corroborate the position of Ogunba and Ajayi (1998) and Babawale and Ajayi (2011), who reported that the level of property valuation inaccuracy prevalent in the Nigerian appraisal practice is unacceptable based on the international standard.

Table 5. Predictive Accuracy of the HPM Technique

\begin{tabular}{lc}
\hline Accuracy metric & Hedonic Pricing Model \\
\hline$r^{2}$ & 0.77 \\
MAPE (\%) & 38.23 \\
MAE & $61,408,856.10$ \\
RMSE & $103,370.573 .40$ \\
\hline
\end{tabular}

The HPM generated from the analysis was used to value the holdout sample in order to establish the predictive accuracy of the HPM technique. The result of the predictions was categorised to establish the percentage of the samples that fell within the acceptable margin and those that did not. The information in Table 6 shows that only $26.67 \%$ of the predicted property values have an error margin of between \pm 0 and $10 \%$, while $13.33 \%$ of the predicted values have an error margin of between \pm 11 and $19 \%$. In addition, $60 \%$ produced an error of $\pm 20 \%$. It is worth mentioning that the inaccuracies recorded are high, resulting in wide disparities between the actual property values and predicted values (see Figure 2).

\section{Table 6. Valuation Accuracy of the HPM Prediction}

\begin{tabular}{lcc}
\hline Accuracy range & Frequency $(\mathrm{n})$ & Percentage (\%) \\
\hline $\pm 0-10 \%$ & 8 & 26.67 \\
$\pm 11-19 \%$ & 4 & 13.33 \\
Above $\pm 20 \%$ & 18 & 60.00
\end{tabular}

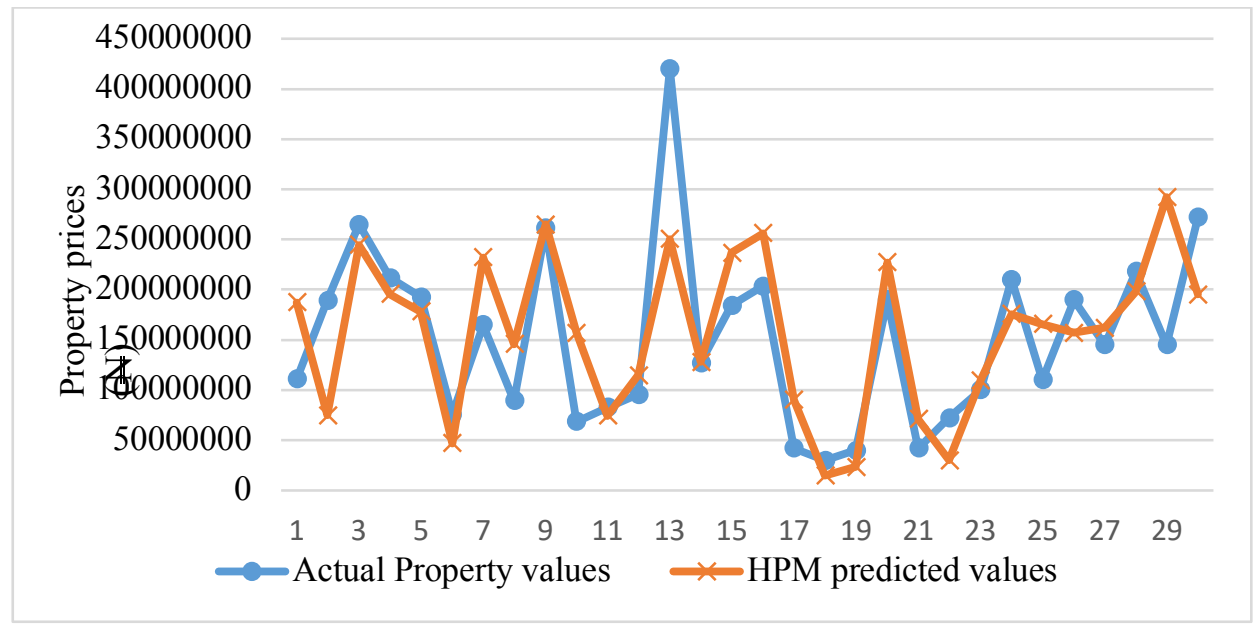

Figure 2: Actual and Predicted Property Values 
These findings appear unsatisfactory, suggesting that the adoption of the HPM technique for property valuation would not produce an accurate and reliable property valuation figure that can be a good proxy for market value. This corroborates the study of Thanasi (2016) conducted in a European market (Albania) and found that the HPM approach could not produce accurate valuation figures. The present study provides an exploration of an investigation from an African property market (Nigeria). One of the implications of this is that the generation of inaccurate property valuation estimates in any property market would continually deepen the loss of the confidence that property valuation end-users place on the real estate profession and professionals. Property valuation inaccuracy could be minimal in stable (developed) property markets (Shapiro et al., 2012). This has been substantiated in the studies of Newell and Kishore (1998) and Parker (1998), among others. Therefore, it is highly imperative that research endeavours be directed at investigating and addressing the factors mitigating against the estimation of accurate property valuation figures, especially in developing economies. If property valuation inaccuracy is reduced to an acceptable standard, this will result in achieving a sustainable property valuation practice.

\section{Conclusion}

The need to establish the predictive accuracy of the HPM technique for property valuation in a developing country necessitated this study. Data for residential properties sold and purchased in the study area were retrieved from registered real estate firms and were used to develop HPM. The evaluation of the HPM developed shows that the approach could not produce accurate property valuation estimates based on the high MAPE, MAE and RMSE values generated. In addition, it was found that a large proportion $(60 \%)$ of the predicted property values produced an error margin of $\pm 20 \%$, which is far above the acceptable industry standard. In order to address the issue of valuation inaccuracy, there is a need to adopt appropriate valuation techniques. This would reduce the investment risk of various real estate investors/stakeholders and this would in turn influence property market stability. The independent variables adopted in this study were mainly structural attributes, whereas locational, neighbourhood and macroeconomic variables were not examined. Also, data were collected from high-income property markets. Subsequently, if all these are explored, different results may be generated. The issue of valuation accuracy cannot be overemphasised due to its influence on the overall economy of any nation. Therefore, research efforts should be continually invested in developing accurate property valuation models that are more suitable in their application within emerging property markets.

\section{Acknowledgements}

The authors sincerely acknowledge the Research Grants Council of Hong Kong (SAR) and the Department of Building and Real Estate, The Hong Kong Polytechnic University, Hong Kong for providing financial and material support toward this research. 


\section{References}

Abidoye, R. B., \& Chan, A. P. C. (2016). A survey of property valuation approaches in Nigeria. Property Management, 34(5), pp.364-382.

Adegoke, J. O. (2014). Critical factors determining rental value of residential property in Ibadan metropolis, Nigeria. Property Management, 32(3), pp.224-240.

Adegoke, O., Olaleye, A., \& Oloyede, S. (2013). A study of valuation clients' perception on mortgage valuation reliability. African Journal of Environmental Science and Technology, 7(7), pp.585-590.

Akinbogun, S., Jones, C., \& Dunse, N. (2014). The property market maturity framework and its application to a developing country: The case of Nigeria. Journal of real estate literature, 22(2), pp.217-232.

Akinjare, O., Oluwunmi, A., \& Iroham, O. (2012). Impact of HVOTLs on residential property rental values in high-brow Lagos metropolis. Ethiopian Journal of Environmental Studies and Management, 5(1), pp.56-63.

Ashaolu, T., \& Olaniran, M. (2016). Valuers' strategies for coping with the dearth of market data in two Nigerian cities: Ibadan and Abeokuta. Pacific Rim Property Research Journal, 22(2), pp.167-179.

Ayan, E., \& Erkin, H. C. (2014). Hedonic modelling for a growing housing market: Valuation of apartments in complexes. International Journal of Economics and Finance, 6(3), pp.188-199.

Babalola, S. J., Umar, A. I., \& Sulaiman, L. A. (2013). An economic analysis of determinants of house rents in the university environment. European Scientific Journal, 9(19), pp.99-111.

Babawale, G. K. (2013a). Valuation accuracy-the myth, expectation and reality! African Journal of Economic and Management Studies, 4(3), pp.387-406.

Babawale, G. K. (2013b). Measuring the impact of church externalities on house prices. Khazar Journal of Humanities \& Social Sciences, 16(4), pp.53-68.

Babawale, G. K., \& Adewunmi, Y. (2011). The impact of neighbourhood churches on house prices. Journal of Sustainable Development, 4(1), pp.246-253.

Babawale, G. K., \& Ajayi, C. A. (2011). Variance in residential property valuation in Lagos, Nigeria. Property Management, 29(3), pp.222237.

Babawale, G. K., \& Johnson, O. (2012). The specification of hedonic indexes for duplexes in Lekki peninsular area of Lagos metropolis. Elixir Social Science, 45(1), pp.7689-7698.

Babawale, G. K., Koleoso, H. A., \& Otegbulu, A. C. (2012). A hedonic model for apartment rentals in Ikeja area of Lagos metropolis. Mediterranean Journal of Social Sciences, 3(3), pp.109-120.

Basu, S., \& Thibodeau, T. G. (1998). Analysis of spatial autocorrelation in house prices. The Journal of Real Estate Finance and Economics, 17(1), pp.61-85.

Benson, E. D., Hansen, J. L., Schwartz Jr, A. L., \& Smersh, G. T. (1998). Pricing residential amenities: The value of a view. The Journal of Real Estate Finance and Economics, 16(1), pp.55-73. 
Berndt, E. R., Cutler, D. M., Frank, R. G., Griliches, Z., Newhouse, J. P., \& Triplett, J. E. (2000). Medical care prices and output. Handbook of Health Economics, 1, pp.119-180.

Bourassa, S. C., \& Peng, V. S. (1999). Hedonic prices and house numbers: The influence of feng shui. International Real Estate Review, 2(1), pp.79-93.

Brown, G. R., Matysiak, G. A., \& Shepherd, M. (1998). Valuation uncertainty and the Mallinson Report. Journal of Property Research, 15(1), pp.113.

Canavarro, C., Caridad, J. M., \& Ceular, N. (2010, 21-24 October). Hedonic methodologies in the real estate valuation. Paper presented at the Mathematical Methods in Engineering International Symposium, Coimbra.

Carroll, T. M., Clauretie, T. M., \& Jensen, J. (1996). Living next to godliness: Residential property values and churches. The Journal of Real Estate Finance and Economics, 12(3), pp.319-330.

Ceccato, V., \& Wilhelmsson, M. (2011). The impact of crime on apartment prices: Evidence from Stockholm, Sweden. Geografiska Annaler: Series B, Human Geography, 93(1), pp.81-103.

Chau, K. W., Ma, V. S., \& Ho, D. C. (2001). The pricing of 'luckiness' in the apartment market. Journal of Real Estate Literature, 9(1), pp.29-40.

Chau, K. W., Wong, S. K., \& Yiu, C. Y. (2004). The value of the provision of a balcony in apartments in Hong Kong. Property Management, 22(3), pp.250-264.

Chiang, Y.-H., Tao, L., \& Wong, F. K. (2015). Causal relationship between construction activities, employment and GDP: The case of Hong Kong. Habitat International, 46(1), pp.1-12.

Chin, T. L., \& Chau, K. W. (2002). A critical review of literature on the hedonic price model. International Journal for Housing Science and Its Applications, 27(2), pp.145-165.

Choy, L. H., Mak, S. W., \& Ho, W. K. (2007). Modelling Hong Kong real estate prices. Journal of Housing and the Built Environment, 22(4), pp.359-368.

Clapp, J. M., Nanda, A., \& Ross, S. L. (2008). Which school attributes matter? The influence of school district performance and demographic composition on property values. Journal of Urban Economics, 63(2), pp.451-466.

Court, A. T. (1939). Hedonic price indexes with automobile examples. The dynamics of the automobile demand. New York: General Motors.

Crosby, N. (2000). Valuation accuracy, variation and bias in the context of standards and expectations. Journal of Property Investment \& Finance, 18(2), pp.130-161.

Crosby, N., Lavers, A., \& Murdoch, J. (1998). Property valuation variation and the'margin of error'in the UK. Journal of Property Research, 15(4), pp.305-330.

Cutler, D. M., \& Berndt, E. R. (2007). Medical care output and productivity (Vol. 62). Chicago and London: University of Chicago Press.

Des Rosiers, F., Lagana, A., Thériault, M., \& Beaudoin, M. (1996). Shopping centres and house values: An empirical investigation. Journal of Property Valuation and Investment, 14(4), pp.41-62. 
Do, A. Q., \& Grudnitski, G. (1992). A neural network approach to residential property appraisal. The Real Estate Appraiser, 58(3), pp.38-45.

Downes, T. A., \& Zabel, J. E. (2002). The impact of school characteristics on house prices: Chicago 1987-1991. Journal of Urban Economics, 52(1), pp.1-25.

Elhag, T. (2002). Tender price modelling: Artificial neural network and regression techniques. (Doctoral dissertation), University of Liverpool, United Kingdom.

Elliott, P., \& Han, H. (2013). Impact of high voltage overhead transmission lines on property value: An Australian residential case study. Retrieved from https://eres.architexturez.net/documents/author/18515. [9 July 2016].

Espey, M., \& Lopez, H. (2000). The impact of airport noise and proximity on residential property values. Growth and Change, 31(3), 408-419.

Famuyiwa, F., \& Babawale, G. K. (2014). Hedonic values of physical infrastructure in-house rentals. Journal of Facilities Management, 12(3), pp.211-230.

Fletcher, M., Gallimore, P., \& Mangan, J. (2000). Heteroscedasticity in hedonic house price models. Journal of Property Research, 17(2), pp.93-108.

Ge, X. J., \& Du, Y. (2007). Main variables influencing residential property values using the entropy method-the case of Auckland. Paper presented at the 5th International Structural Engineering and Construction Conference, Shunan, Japan.

Goodhart, C., \& Hofmann, B. (2008). House prices, money, credit, and the macroeconomy. Oxford Review of Economic Policy, 24(1), pp.180205.

Gujarati, D. N., \& Porter, D. C. (2009). Basic econometrics (5th ed.). Boston: McGraw-Hill Education.

Haas, G. C. (1922). A statistical analysis of farm sales in blue earth county, Minnesota, as a basis for farmland appraisal. (Master's Thesis), University of Minnesota, United States of America. Retrieved from http://ageconsearch.umn.edu/handle/184329 [18 July 2016].

Hager, D. P., \& Lord, D. J. (1985). The property market, property valuations and property performance measurement. Journal of the Institute of Actuaries, 112(1), pp.19-60.

Hui, E. C., Chau, C., Pun, L., \& Law, M. (2007). Measuring the neighbouring and environmental effects on residential property value: Using spatial weighting matrix. Building and environment, 42(6), pp.2333-2343.

Hutchinson, N., MacGregor, B., Nanthakumaran, N., Adair, A., \& McGreal, S. (1996). Variations in the capital valuations of UK commercial property. London: Royal Institute of Chartered Surveyors.

Jenkins, D. (2000). Residential valuation theory and practice. Oxford: Chandos Publishing.

Jim, C., \& Chen, W. Y. (2006). Impacts of urban environmental elements on residential housing prices in Guangzhou (China). Landscape and Urban Planning, 78(4), pp.422-434.

Kmenta, J. (1997). Elements of Econometrics (2nd ed.). New York: Macmillan. 
Kryvobokov, M., \& Wilhelmsson, M. (2007). Analysing location attributes with a hedonic model for apartment prices in Donetsk, Ukraine. International Journal of Strategic Property Management, 11(3), pp.157-178.

Lam, K. C., Yu, C. Y., \& Lam, K. Y. (2008). An artificial neural network and entropy model for residential property price forecasting in Hong Kong. Journal of Property Research, 25(4), pp.321-342.

Lancaster, K. J. (1966). A new approach to consumer theory. Journal of political economy, 74(2), pp.132-157.

Limsombunchai, V., Gan, C., \& Lee, M. (2004). House price prediction: Hedonic price model vs. artificial neural network. American Journal of Applied Sciences, 1(3), pp.193-201.

Lin, C. C., \& Mohan, S. B. (2011). Effectiveness comparison of the residential property mass appraisal methodologies in the USA. International Journal of Housing Markets and Analysis, 4(3), pp.224243.

Mackmin, D. (1985). Is there a residential valuer in the house? Journal of Valuation, 3(4), pp.384-390.

Mbachu, J. I., \& Lenono, N. (2005, 4-8 July). Factors influencing market values of residential properties. Paper presented at the Queensland University of Technology Research Week International Conference, Brisbane, Australia.

McCluskey, W. J., McCord, M., Davis, P., Haran, M., \& McIlhatton, D. (2013). Prediction accuracy in mass appraisal: A comparison of modern approaches. Journal of Property Research, 30(4), pp.239265.

McGreal, S., Adair, A., McBurney, D., \& Patterson, D. (1998). Neural networks: The prediction of residential values. Journal of Property Valuation and Investment, 16(1), pp.57-70.

Moghimi, V., \& Jusan, M. B. M. (2015). Priority of structural housing attribute preferences: Identifying customer perception. International Journal of Housing Markets and Analysis, 8(1), pp.36-52.

Mok, H. M., Chan, P. P., \& Cho, Y.-S. (1995). A hedonic price model for private properties in Hong Kong. The Journal of Real Estate Finance and Economics, 10(1), pp.37-48.

Mora-Esperanza, J. G. (2004). Artificial intelligence applied to real estate valuation: An example for the appraisal of Madrid. CATASTRO, April (1), pp.255-265.

Morancho, A. B. (2003). A hedonic valuation of urban green areas. Landscape and Urban Planning, 66(1), pp.35-41.

Muth, R. F. (1966). Household production and consumer demand functions. Econometrica, 34(3), pp.699-708.

National Bureau of Statistics. (2016). Consumer Price Index (CPI) June 2016 (Publication no. http://www.nigerianstat.gov.ng/report/413). (No. 555). Retrieved 18th July 2016, from NBS

Nelson, R. A., Tanguay, T. L., \& Patterson, C. D. (1994). A quality-adjusted price index for personal computers. Journal of Business \& Economic Statistics, 12(1), pp.23-31. 
Newell, G., \& Kishore, R. (1998, 19-21 January). The accuracy of commercial property valuations. Paper presented at the 4th Pacific Rim Real Estate Society Conference, Perth.

Nguyen, N., \& Cripps, A. (2001). Predicting housing value: A comparison of multiple regression analysis and artificial neural networks. Journal of Real Estate Research, 22(3), pp.313-336.

Nicholls, S., \& Crompton, J. L. (2005). The impact of greenways on property values: Evidence from Austin, Texas. Journal of Leisure Research, 37(3), pp.321-341.

Oduwole, H., \& Eze, H. (2013). A hedonic pricing model on factors that influence residential apartment rent in Abuja satellite towns. Mathematical Theory and Modelling, 3(12), pp.65-73.

Ogunba, O., \& Ajayi, C. (1998). An assessment of the accuracy of valuations in the residential property market of Lagos. The Estate Surveyor and Valuer, 21(2), pp.19-23.

Ohta, M., \& Griliches, Z. (1976). Automobile prices revisited: Extensions of the hedonic hypothesis. In N. E. Terleckyj (Ed.), Household production and consumption (pp.325-398). New York: NBER.

Otegbulu, A., \& Johnson, O. (2011). The impact of Jacuzzi bathtubs on house prices. Journal of Sustainable Development, 4(3), pp.199-209.

Ottensmann, J. R., Payton, S., \& Man, J. (2008). Urban location and housing prices within a hedonic model. Journal of Regional Analysis and Policy, 38(1), pp.19-35.

Owusu-Ansah, A. (2012). Examination of the determinants of housing values in urban Ghana and implications for policymakers. Journal of African Real Estate Research, 2(1), pp.58-85.

Pagourtzi, E., Assimakopoulos, V., Hatzichristos, T., \& French, N. (2003). Real estate appraisal: A review of valuation methods. Journal of Property Investment \& Finance, 21(4), pp.383-401.

Parker, D. (1998, 19-21 January). Valuation accuracy - An Australian perspective. Paper presented at the 4th Pacific Rim Real Estate Society Conference, Perth.

Powe, N., Garrod, G., \& Willis, K. (1995). Valuation of urban amenities using a hedonic price model. Journal of Property Research, 12(2), pp.137147.

Pozo, A. G. (2009). A nested housing market structure: Additional evidence. Housing Studies, 24(3), pp.373-395.

Ready, R. (2010). Do landfills always depress nearby property values? Journal of Real Estate Research, 32(3), pp.321-339.

Ridker, R. G., \& Henning, J. A. (1967). The determinants of residential property values with special reference to air pollution. The Review of Economics and Statistics, 49(2), pp.246-257.

Rosen, S. (1974). Hedonic prices and implicit markets: Product differentiation in pure competition. The journal of political economy, 82(1), pp.34-55.

Sanjari, H. (2012). Estimation of the hedonic pricing function for housing units (A case study of Hashtgerd New Town, Iran). International Business Management, 6(6), pp.676-679.

Schwartz, T. J. (1995). Automating appraisal. Wall Street \& Technology, 12(13), pp.64-66. 
Selim, H. (2009). Determinants of house prices in Turkey: Hedonic regression versus artificial neural network. Expert Systems with Applications, 36(2), pp.2843-2852.

Selim, S. (2011). Determinants of house prices in Turkey: A hedonic regression model. Doğuş Üniversitesi Dergisi, 9(1), pp.65-76.

Seok Lim, J., \& Missios, P. (2007). Does size really matter? Landfill scale impacts on property values. Applied Economics Letters, 14(10), pp.719-723.

Shapiro, E., Mackmin, D., \& Sams, G. (2012). Modern methods of valuation (11th ed.). London: Estates Gazette.

Shmueli, G. (2010). To explain or to predict? Statistical Science, 25(3), pp.289-310.

Silver, M., \& Heravi, S. (2001). Scanner data and the measurement of inflation. The Economic Journal, 111(472), pp.383-404.

Sims, S., Dent, P., \& Ennis-Reynolds, G. (2009). Calculating the cost of overheads: the real impact of HVOTLs on house price. Property Management, 27(5), pp.319-347.

Sirmans, S. G., Macpherson, D. A., \& Zietz, E. N. (2005). The composition of hedonic pricing models. Journal of Real Estate Literature, 13(1), pp.1-44.

Sirpal, R. (1994). Empirical modelling of the relative impacts of various sizes of shopping centres on the values of surrounding residential properties. Journal of Real Estate Research, 9(4), pp.487-505.

Taffese, W. Z. (2007, 12-14, February). Case-based reasoning and neural networks for real estate valuation. Paper presented at the 25 th IASTED International Conference on Artificial Intelligence and Applications, Innsbruck, Austria.

Thanasi, M. (2016). Hedonic appraisal of apartments in Tirana. International Journal of Housing Markets and Analysis, 9(2), pp.239-255.

Tomkins, J., Topham, N., Twomey, J., \& Ward, R. (1998). Noise versus access: The impact of an airport in an urban property market. Urban Studies, 35(2), pp.243-258.

Topcu, M., \& Kubat, A. S. (2009, 8-11, June). The analysis of urban features that affect land values in residential areas. Paper presented at the 7 th International Space Syntax Symposium, KTH, Stockholm.

Triplett, J. (2004). Handbook on hedonic indexes and quality adjustments in price indexes: Special application to information technology products , pp.1815-1965. OECD Publishing, Paris. DOI: https://doi.org/10.1787/9789264028159-en.

Tse, R. Y. (2002). Estimating neighbourhood effects in house prices: Towards a new hedonic model approach. Urban Studies, 39(7), pp.1165-1180.

Tse, R. Y., \& Love, P. E. (2000). Measuring residential property values in Hong Kong. Property Management, 18(5), pp.366-374.

Voicu, I., \& Been, V. (2008). The effect of community gardens on neighbouring property values. Real Estate Economics, 36(2), pp.241283.

Waldy, B. (1997, 11-16, May). Valuation accuracy. Paper presented at the 64th FIG Permanent Committee Meeting and International Symposium, Singapore. 
Wallace, H. A. (1926). Comparative farm-land values in Iowa. The Journal of Land \& Public Utility Economics, 2(4), pp.385-392.

Wen, H.-Z., Jia, S.-H., \& Guo, X.-Y. (2005). Hedonic price analysis of urban housing: An empirical research on Hangzhou, China. Journal of Zhejiang University Science, 6 A (8), pp.907-914.

Willmott, C. J. (1981). On the validation of models. Physical geography, 2(2), pp.184-194.

Yalpir, S. (2014, 15-17, October). Forecasting residential real estate values with AHP method and integrated GIS. Paper presented at the People, Buildings and Environment Conference, an International Scientific Conference, Kroměříž, Czech Republic. 